\title{
FEED VALUE OF MAIZE (Zea mays var. indentata (Sturtev.) L.H.Bailey) GRAIN UNDER DIFFERENT IRRIGATION LEVELS AND NITROGEN DOSES
}

\author{
Hasan KALE ${ }^{I^{*}}$ Mahmut KAPLAN ${ }^{2}$ Ismail ULGER ${ }^{3}$ Ali UNLUKARA ${ }^{4}$ Taner AKAR \\ ${ }^{1}$ Bozok University, Bogazliyan Vocational School, Department of Crops and Animal Science, Yozgat, \\ TURKEY \\ ${ }^{2}$ Erciyes University, Faculty of Agriculture, Department of Field Crops, Kayseri, TURKEY \\ ${ }^{3}$ Erciyes University, Faculty of Agriculture, Department of Animal Science, Kayseri, TURKEY \\ ${ }^{4}$ Erciyes University, Faculty of Agriculture, Department of Biosystem Engineering, Kayseri, TURKEY \\ ${ }^{5}$ Akdeniz University, Faculty of Agriculture, Department of Field Crops, Antalya, TURKEY \\ *Corresponding author: hsnkale_46@hotmail.com
}

Received: 07.02.2018

\begin{abstract}
The aim of the study was to investigate effects of different irrigation levels and nitrogen doses to chemical composition, in vitro gas and methane production of maize kernel for animal feeding. Three different nitrogen doses such as 100, 200 and $300 \mathrm{~kg} \mathrm{ha}^{-1} \mathrm{~N}$ and irrigation levels such as $50 \%, 75 \%$ and $100 \%$ of depleted water were applied. The study was carried out under split plot for randomized complete block experimental design with three replicates during 2013-2014 seasons and irrigation levels were allocated in to main plots while nitrogen doses in to sub plots. The two-year results of the study showed that crude protein, crude ash and crude oil ratios and gas and methane production, metabolic energy (ME) and organic matter digestibility (OMD) were positively affected by increased level of water levels and nitrogen doses while acid detergent fiber (ADF) and neutral detergent fiber (NDF) and dry matter contents were negatively affected. It is clear that increased level of water and nitrogen positively contributed to quality of maize kernel for animal production but more researches are needed to explain how increased level of water and nitrogen result in higher level of gas and methane production.
\end{abstract}

Keywords: Chemical composition, in vitro gas production, maize grain, nitrogen application, water deficit

\section{INTRODUCTION}

Maize (Zea mays L.) grain is mainly consumed by food and feed for human, wild and domesticated animals, respectively. It is also used as raw material for starch, oil, sugar, celluloses and ethyl alcohol production (Kirtok, 1998). Maize starch, protein, oil and minerals production are under effects of genetics and environments (Baenziger et al., 2001). Moreover, cultivation practice is also another factor affecting maize grain yield and quality. Irrigation and fertilization are the most important cultivation practice factors for plant production (Khelil et al., 2013). Use of excessive water and nitrogen can result in environmental pollution (Ferrer et al., 1997), extra cost and negative effects on soil (Khelil et al., 2013) but inadequate use of these dramatically decrease grain yield and quality, too. Available irrigation water is limited and costly so that reason urgent precautions should be taken in to consideration for water preservation without any yield penalty in plant production Oktem (2008). On the other hand, excessive nitrogen application is one of important pollutants for water reserves and also threatens human health and animal welfare (Rahman et al., 2008). Nitrogen and water application synergistically affect grain yield and plant nutrient use (Kim et al., 2008). This situation directly and positively affects grain yield and quality of plants so that reason use of these two components should be optimized.

Determination of chemical composition, energy level and digestibility is utmost importance to explain difference between feed stuff Canbolat (2012). For this aim, in vitro gas production developed by Menke et al. (1979) has been intensively used due to the fact that is rapid, easy and cost effective method (Kaplan et al., 2014). Gas production method is also used to determine methane reduction potential of feeds which contributes global warming (Lin et al., 2013).

Irrigation and nitrogen have been separately used in many studies but they are barely used altogether in maize production. Moreover, many studies focused on silage yield and quality, and relationship between physiological traits and irrigation and nitrogen use. The aim of this study was to determine effects of maize grain cultivated under 
different water deficit conditions and nitrogen doses to some animal feeding parameters.

\section{MATERIALS AND METHODS}

The experiments were carried out during spring of 2013 and 2014 seasons under Kayseri provinces of Turkey. Simon maize variety (Zea mays var indenta) was used as plant material considering its common adoption and higher grain yield in the region. The variety was planted with $70 \times 16 \mathrm{~cm}$ spacing in to the plots by $6 \times 4.2 \mathrm{~m}$ dimensions (Kusvuran et al., 2015) and three different irrigation levels (I50: 50\%, I75: 75\% and I100: 100\% of depleted water) and nitrogen doses (N1: 100, N2: 200 and N3: $300 \mathrm{~kg} \mathrm{ha}^{-1} \mathrm{~N}$ ) were the research subjects. Soil moisture content was measured with a neutron probe and the amount of irrigation water to be applied was determined and applied through a drip irrigation method. The study was setup under split plot experimental design with three replications, main plots were irrigation levels, and sub-plots were nitrogen doses. Plants were weekly irrigated by drop irrigation method based on neutron meter calculations. Half of the all nitrogen doses and whole of the phosphorus $\left(\mathrm{P}_{2} \mathrm{O}_{5}, 100 \mathrm{~kg} \mathrm{ha}^{-1}\right)$ based on soil analysis were applied during sowing and remaining of the nitrogen was applied when plants reached $50 \mathrm{~cm}$ plant heights (Gul et al., 2008). The weeds were treated by herbicide after emergence (V3) and all other cultural practices were applied till harvest and plants were harvested for chemical analyses at physiological maturity (R6).

\section{Soil and Climate Characteristics of Experimental Sites}

The climate data of experimental site are given in the Table 1. The first year, plants were sown on $23^{\text {rd }}$ of the April 2013 while they were sown and on $28^{\text {rd }}$ of the April 2014 in the second year. Temperature of 2013 and 2014 seasons were almost the same compared to that of longterm. Precipitation during 2013 season was lower than long term while it was higher than long term average during 2014 seasons. Relative moisture of cultivation seasons were higher than long term average.

Table 1. Precipitation, temperature, and relative moisture data of experimental site

\begin{tabular}{lccccccccc}
\hline \multirow{2}{*}{ Months } & \multicolumn{3}{c}{ Temperature $\left({ }^{\circ} \mathbf{C}\right)$} & \multicolumn{3}{c}{ Precipitation $(\mathbf{m m})$} & \multicolumn{3}{c}{ Relative Humidity $(\%)$} \\
\cline { 2 - 9 } & $\mathbf{2 0 1 3}$ & $\mathbf{2 0 1 4}$ & Long Term* & $\mathbf{2 0 1 3}$ & $\mathbf{2 0 1 4}$ & Long Term* & $\mathbf{2 0 1 3}$ & $\mathbf{2 0 1 4}$ & Long Term* \\
\hline April & 12.1 & 14.1 & 10.7 & 43.6 & 2.9 & 54.8 & 56.2 & 44.3 & 62.6 \\
May & 18.1 & 16.7 & 15.1 & 31.3 & 39.7 & 52.0 & 44.7 & 50.4 & 60.8 \\
June & 21.1 & 19.7 & 19.1 & 12.6 & 52.9 & 39.1 & 38.7 & 46.8 & 55.3 \\
July & 22.5 & 25.2 & 22.6 & 3.4 & 0.0 & 10.3 & 36.9 & 33.7 & 49.5 \\
August & 22.5 & 25.1 & 22.0 & 0.8 & 47.4 & 5.3 & 36.0 & 37.4 & 49.8 \\
September & 17.0 & 18.8 & 17.1 & 10.3 & 85.4 & 13.3 & 44.1 & 54.2 & 54.4 \\
October & 9.2 & 11.7 & 11.5 & 52.5 & 54.4 & 30.5 & 58.9 & 68.1 & 64.0 \\
Mean & 17.5 & 18.7 & 16.8 & - & - & - & 45.0 & 47.8 & 56.6 \\
Total & - & - & - & 154.5 & 282.7 & 205.3 & - & - & - \\
\hline
\end{tabular}

*from 1970 to 2013

Physical and chemical properties of the soils of the experimental site are given in the Table 2. Soils of the experimental site are classified as sandy- loamy sampled at $0-30 \mathrm{~cm}$ and $30-60 \mathrm{~cm}$ depths. Calcareous and salt were low while potassium and phosphorus were rich in the soil. Soil pH was slightly alkaline but organic matter content was quite low.

Table 2. Physical and chemical characteristics of soils of the experimental site

\begin{tabular}{lcccc}
\hline \multirow{2}{*}{ Property } & \multicolumn{2}{c}{$\mathbf{2 0 1 3}$} & & $\mathbf{2 0 1 4}$ \\
\cline { 2 - 5 } & $\mathbf{0 - 3 0} \mathbf{~ c m}$ & $\mathbf{3 0 - 6 0 ~ c m}$ & $\mathbf{0 - 3 0 ~ c m ~}$ & $\mathbf{3 0 - 6 0 ~ c m ~}$ \\
\hline Clay $(\%)$ & 13.10 & 8.94 & 12.58 & 9.18 \\
Silt $(\%)$ & 4.16 & 10.40 & 5.11 & 9.55 \\
Sand $(\%)$ & 82.74 & 80.66 & 82.31 & 81.27 \\
Class & Sandy-Loamy & Sandy-Loamy & Sandy-Loamy & Sandy-Loamy \\
pH & 7.94 & 7.75 & 7.48 & 7.60 \\
Organic Matter $(\%)$ & 1.05 & 1.27 & 1.09 & 1.14 \\
$\mathrm{CaCO}_{3}(\%)$ & 0.28 & 0.27 & 0.24 & 0.29 \\
$\mathrm{~K}_{2} \mathrm{O}\left(\mathrm{kg} \mathrm{ha}^{-1}\right)$ & 1092.20 & 755.14 & 1184.20 & 842.34 \\
$\mathrm{P}_{2} \mathrm{O}_{5}\left(\mathrm{~kg} \mathrm{ha}^{-1}\right)$ & 89.63 & 11.56 & 110.41 & 12.58 \\
$\mathrm{EC}\left(\mathrm{mmhos} \mathrm{cm}^{-1}\right)$ & 0.96 & 0.23 & 0.83 & 0.27 \\
\hline
\end{tabular}




\section{Feed Samples and Chemical composition analyses}

Dry matter content of maize grain harvested at physiological maturity (R6) was determined at $70{ }^{\circ} \mathrm{C}$ for 48 hours. Then, they were grounded by using $1 \mathrm{~mm}$ sieve experimental mill. Crude ash content of the samples were determined by using ash oven at $550{ }^{\circ} \mathrm{C}$ for 8 hours and ether extraction method was used to analyze crude oil content by using Soxhlet collector (AOAC, 1990). N content of the maize samples was determined by Kjeldahl method then protein content was calculated via multiplying $\mathrm{N}$ content by 6.25 formula (AOAC 1990). NDF (Van Soest and Wine, 1967) and ADF (Van Soest, 1963) contents were analyzed by using ANKOM 200 Fiber Analyzer (ANKOM Technology Corp. Fairport, NY, USA)

\section{Gas and Methane Measuring}

Effects of different water deficits and nitrogen doses on the maize grain's gas and methane production was analyzed by using in vitro gas production method (Menke et al., 1979). Rumen liquor was taken via rumen fistula of three sheep fed by special ratio including $60 \%$ alfalfa and $40 \%$ barley grain. Rumen liquor was always taken before morning feeding and filtered by using six fold cheesecloth then mixed 1:2 buffer solution. Four replicates of $0.2 \mathrm{~g}$ ground grain samples were transferred in to the $100 \mathrm{ml}$ syringe and then this was complemented by $30 \mathrm{ml}$ buffered rumen liquor. All syringes consisted of grain samples and buffer rumen liquor were put into the water bath at $39{ }^{\circ} \mathrm{C}$. In addition to these, four syringes consisted of only buffered rumen liquor were also incubated. Net gas production was calculated by subtracting gas production of these syringes from that of all syringes. Maize grains were incubated during 24 hours and total gas volume (mL) was also measured. All gases were transferred via plastic syringes to infrared methane analyzer (Sensor Europe GmbH, Erkrath, Germany) and methane percentage was determined (Goel et al., 2008). Methane production was calculated by using the formula below: (\%)

Methane production $(\mathrm{mL})=$ Total gas $(\mathrm{mL}) \times$ Methane

\section{Determination of metabolic energy and organic matter digestibility of the samples}

Metabolic energy content of the maize grain was calculated by using gas production for 24 hours and some parameter related to chemical composition Menke and Steingass (1988) as indicated below:

$$
\begin{gathered}
\mathrm{ME}\left(\mathrm{MJ} \mathrm{kg}^{-1} \mathrm{DM}\right)=2.20+0.136 \mathrm{GP}+0.057 \mathrm{CP}+ \\
0.002859 \mathrm{CO}^{2} \\
\mathrm{OMD}(\%)=14.88+0.889 \mathrm{GP}+0.45 \mathrm{CP}+0.0651 \mathrm{CA}
\end{gathered}
$$

In this formulas:

DM: Dry matter; GP: Net gas production for 24 hours $(\mathrm{mL}) \mathrm{CP}$ : Crude protein (\%); CO: Crude oil (\%); CA: Crude ash (\%); OMD: Organic matter digestibility (\%).

\section{Statistical analysis}

The two-year experimental data were subjected to variance analysis with SAS (SAS Inst, 1999) statistical software and then significance of the difference among the means were analyzed by using LSD test.

\section{RESULTS}

Water deficit and nitrogen doses the most significantly affected maize grain composition $(\mathrm{P} \leq 0.01)$. Experimental season significantly affected crude protein content $(\mathrm{P} \leq 0.05)$ while $\mathrm{DM}, \mathrm{ADF}, \mathrm{NDF}$ and crude oil content were the most significantly affected by cultivation seasons $(\mathrm{P} \leq 0.01)$. However, crude ash wasn't statistically affected by seasonal difference (Table 3). Irrigation level and nitrogen dose interaction on chemical composition were not significant (Table 3). Increased irrigation positively contributed to dry mater content of maize grain while nitrogen doses negatively contributed to this. Moreover, increased irrigation and nitrogen doses positively contributed to crude oil content. Crude oil content changed 3.24-3.80 \% and 3.45-3.60\% depending on nitrogen doses and water deficit regimes, respectively.

Cell wall components such as ADF and NDF were decreased based on increased irrigation and nitrogen doses. The highest and lowest ADF and NDF rates were obtained as 4.76 and $24.56 \%$, and 4.40 and $20.56 \%$ by I50 and I100 irrigation applications, respectively. Increase on irrigation and nitrogen doses positively affected crude protein and ash content. Water deficit resulted in the lowest $(9.14 \%)$ at I50 and the highest crude protein content $(10.22 \%)$ at I100 applications. The same results were also obtained by nitrogen doses and the lowest crude protein content was $8.63 \%$ at N1 while the highest one $10.40 \%$ at $\mathrm{N} 3$ doses. The lowest crude ash content gathered I50 (1.22\%) and N1 (1.17\%) combination while the highest one from $\mathrm{I} 100(1.37 \%)$ and $\mathrm{N} 3(1.39 \%)$ combination (Table 3).

Mean values of gas and methane production, metabolic energy ad organic matter digestibility of the maize grain under water deficit and nitrogen doses were given at Table 4. Water deficit and nitrogen doses significantly affected gas and methane production, ME and OMD of the maize grain at $\% 1$ level. Seasonal difference was also the most significant effect on maize grain $(\mathrm{P} \leq 0.01)$ while water deficit and nitrogen dose interaction was effective on only methane production at $\% 1$ level. Moreover, increased irrigation and nitrogen doses positively affected methane production. I50 (66.31 $\mathrm{mL})$ and $\mathrm{N} 1 \quad(66.14 \mathrm{~mL})$ applications resulted in the lowest gas production while I100 (70.44 mL) and N3 (70.52 mL) applications resulted in the highest one. Methane rate changed between 8.28$9.79 \mathrm{~mL}$ under irrigation levels condition. The lowest methane rate was obtained $175 \mathrm{xN} 1$ applications while the highest one from I100xN3 applications. ME and OMD positively reacted to increased nitrogen doses. The highest ME values were obtained by I 100 (11.82 $\left.\mathrm{MJ} \mathrm{kg}^{-1} \mathrm{DM}\right)$ and N3 (11.83 $\left.\mathrm{MJ} \mathrm{kg}^{-1} \mathrm{DM}\right)$ applications while the lowest 
ME values from I $50\left(11.26 \mathrm{MJ} \mathrm{kg}^{-1} \mathrm{DM}\right)$ and N1 (11.23 $\left.\mathrm{MJ} \mathrm{kg}{ }^{-1} \mathrm{DM}\right)$ applications. The highest and the lowest OMD gathered with $75.22 \%$ and $75.29 \%, 71.74 \%$ and
$71.53 \%$ by $\mathrm{I} 100$ and N3, and I50 and N1 applications, respectively.

Table 3. Chemical composition of maize grain under different water deficit and nitrogen levels

\begin{tabular}{|c|c|c|c|c|c|c|c|c|c|}
\hline \multirow{3}{*}{$\begin{array}{c}\text { Irrigation } \\
\text { Level }\end{array}$} & \multicolumn{4}{|c|}{ Dry Matter (\%) } & \multirow{3}{*}{$\begin{array}{c}\text { Irrigation } \\
\text { Level }\end{array}$} & \multicolumn{4}{|c|}{ Crude Oil (\%) } \\
\hline & \multicolumn{3}{|c|}{ Fertilizer Doses } & \multirow[t]{2}{*}{ Means } & & \multicolumn{3}{|c|}{ Fertilizer Doses } & \multirow[t]{2}{*}{ Means } \\
\hline & N1 & N2 & N3 & & & N1 & $\mathbf{N 2}$ & N3 & \\
\hline I 50 & 82.76 & 82.24 & 79.98 & $81.66^{a}$ & I 50 & 3.15 & 3.45 & 3.74 & $3.45^{\mathrm{b}}$ \\
\hline I 75 & 82.50 & 81.31 & 76.19 & $80.00^{\mathrm{a}}$ & I 75 & 3.23 & 3.54 & 3.82 & $3.53^{\mathrm{ab}}$ \\
\hline I 100 & 77.69 & 76.61 & 72.74 & $75.68^{b}$ & I 100 & 3.34 & 3.62 & 3.85 & $3.60^{\mathrm{a}}$ \\
\hline Means & $80.98^{\mathrm{a}}$ & $80.05^{a}$ & $76.30^{b}$ & & Means & $3.24^{\mathrm{c}}$ & $3.54^{b}$ & $3.80^{\mathrm{a}}$ & \\
\hline \multicolumn{5}{|c|}{ Irri: **; Fert: ${ }^{* * ;}$ Irri $x$ Fertilizer:N.S.; Year: ${ }^{* *}$} & \multicolumn{5}{|c|}{ Irri: **; Fert: **; Irri x Fertilizer:N.S.; Year:N.S. } \\
\hline \multirow{3}{*}{$\begin{array}{c}\text { Irrigation } \\
\text { Level }\end{array}$} & \multicolumn{4}{|c|}{ ADF (\%) } & \multirow{3}{*}{$\begin{array}{c}\text { Irrigation } \\
\text { Level }\end{array}$} & \multicolumn{4}{|c|}{ NDF (\%) } \\
\hline & \multicolumn{3}{|c|}{ Fertilizer Doses } & Means & & \multicolumn{3}{|c|}{ Fertilizer Doses } & Means \\
\hline & N1 & N2 & N3 & & & N1 & $\mathbf{N 2}$ & N3 & \\
\hline I 50 & 5.10 & 4.72 & 4.45 & $4.76^{\mathrm{a}}$ & I 50 & 25.64 & 24.26 & 23.78 & $24.56^{\mathrm{a}}$ \\
\hline I 75 & 4.93 & 4.61 & 4.24 & $4.59^{\mathrm{ab}}$ & I 75 & 23.91 & 22.47 & 21.61 & $22.67^{b}$ \\
\hline I 100 & 4.69 & 4.52 & 4.00 & $4.40^{\mathrm{b}}$ & I 100 & 21.02 & 20.64 & 20.02 & $20.56^{\mathrm{c}}$ \\
\hline Means & $4.91^{\mathrm{a}}$ & $4.62^{b}$ & $4.23^{\mathrm{c}}$ & & Means & $23.52^{\mathrm{a}}$ & $22.46^{\mathrm{b}}$ & $21.80^{\mathrm{b}}$ & \\
\hline \multicolumn{5}{|c|}{ Irri: **; Fert: **; Irri x Fertilizer:N.S.; Year:** } & \multicolumn{5}{|c|}{ Irri: **; Fert: **; Irri x Fertilizer:N.S.; Year:** } \\
\hline \multirow{3}{*}{$\begin{array}{c}\text { Irrigation } \\
\text { Level }\end{array}$} & \multicolumn{4}{|c|}{ Crude Protein (\%) } & \multirow{3}{*}{$\begin{array}{c}\text { Irrigation } \\
\text { Level }\end{array}$} & \multicolumn{4}{|c|}{ Crude Ash (\%) } \\
\hline & \multicolumn{3}{|c|}{ Fertilizer Doses } & Means & & \multicolumn{3}{|c|}{ Fertilizer Doses } & Means \\
\hline & N1 & N2 & N3 & & & N1 & $\mathbf{N 2}$ & N3 & \\
\hline I 50 & 8.24 & 9.32 & 9.85 & $9.14^{\mathrm{b}}$ & I 50 & 1.06 & 1.27 & 1.34 & $1.22^{b}$ \\
\hline I 75 & 8.54 & 9.43 & 10.01 & $9.33^{\mathrm{b}}$ & I 75 & 1.15 & 1.31 & 1.39 & $1.28^{\mathrm{ab}}$ \\
\hline I 100 & 9.11 & 10.21 & 11.34 & $10.22^{\mathrm{a}}$ & I 100 & 1.31 & 1.36 & 1.45 & $1.37^{\mathrm{ab}}$ \\
\hline Means & $8.63^{\mathrm{c}}$ & $9.65^{b}$ & $10.40^{\mathrm{a}}$ & & Means & $1.17^{\mathrm{b}}$ & $1.31^{\mathrm{a}}$ & $1.39^{\mathrm{a}}$ & \\
\hline \multicolumn{5}{|c|}{ Irri: **; Fert: **; Irrix Fertilizer:N.S.; Year:* } & \multicolumn{5}{|c|}{ Irri: **; Fert: **; Irri x Fertilizer:N.S.; Year:N.S. } \\
\hline
\end{tabular}

Table 4. Gas and methane production, metabolic energy and organic matter digestibility of maize grain under different water deficit and nitrogen levels

\begin{tabular}{|c|c|c|c|c|c|c|c|c|c|}
\hline \multirow{3}{*}{$\begin{array}{c}\text { Irrigation } \\
\text { Level }\end{array}$} & \multicolumn{4}{|c|}{ Gas Production (mL) } & \multirow{3}{*}{$\begin{array}{c}\text { Irrigation } \\
\text { Level }\end{array}$} & \multicolumn{4}{|c|}{$\mathrm{CH}_{4}(\mathrm{~mL})$} \\
\hline & \multicolumn{3}{|c|}{ Fertilizer Doses } & \multirow[t]{2}{*}{ Means } & & \multicolumn{3}{|c|}{ Fertilizer Doses } & \multirow[t]{2}{*}{ Means } \\
\hline & N1 & N2 & N3 & & & N1 & N2 & N3 & \\
\hline I 50 & 63.79 & 66.08 & 69.21 & $66.31^{b}$ & I 50 & 8.89 & 8.95 & 8.54 & $8.79^{b}$ \\
\hline I 75 & 65.58 & 67.00 & 70.27 & $67.62^{b}$ & I 75 & 8.28 & 8.50 & 9.33 & $8.70^{b}$ \\
\hline I 100 & 69.04 & 70.21 & 72.08 & $70.44^{\mathrm{a}}$ & I 100 & 9.35 & 9.16 & 9.79 & $9.43^{\mathrm{a}}$ \\
\hline Means & $66.14^{\mathrm{c}}$ & $67.76^{b}$ & $70.52^{a}$ & & Means & $8.84^{b}$ & $8.87^{b}$ & $9.22^{\mathrm{a}}$ & \\
\hline
\end{tabular}
Irri: **; Fert: **; Irrix Fertilizer:N.S.; Year:N.S. Irri: **; Fert: **; Irri $x$ Fertilizer:N.S.; Year:**

\begin{tabular}{|c|c|c|c|c|c|c|c|c|c|}
\hline \multirow{3}{*}{$\begin{array}{c}\text { Irrigation } \\
\text { Level }\end{array}$} & \multicolumn{4}{|c|}{ Metabolic Energy (MJ kg-1 DM) } & \multirow{3}{*}{$\begin{array}{c}\text { Irrigation } \\
\text { Level }\end{array}$} & \multicolumn{4}{|c|}{ Organic Matter Digestibility (\%) } \\
\hline & \multicolumn{3}{|c|}{ Fertilizer Doses } & \multirow[t]{2}{*}{ Means } & & \multicolumn{3}{|c|}{ Fertilizer Doses } & \multirow[t]{2}{*}{ Means } \\
\hline & N1 & N2 & N3 & & & N1 & $\mathbf{N 2}$ & N3 & \\
\hline I 50 & 10.91 & 11.23 & 11.65 & $11.26^{\mathrm{b}}$ & I 50 & 69.54 & 71.51 & 74.17 & $71.74^{b}$ \\
\hline I 75 & 11.15 & 11.35 & 11.80 & $11.43^{b}$ & I 75 & 71.06 & 72.29 & 75.07 & $72.81^{\mathrm{b}}$ \\
\hline I 100 & 11.62 & 11.79 & 12.05 & $11.82^{\mathrm{a}}$ & I 100 & 74.01 & 75.02 & 76.63 & $75.22^{a}$ \\
\hline Means & $11.23^{\mathrm{c}}$ & $11.46^{\mathrm{b}}$ & $11.83^{\mathrm{a}}$ & & Means & $71.53^{\mathrm{c}}$ & $72.94^{b}$ & $75.29^{a}$ & \\
\hline
\end{tabular}

Irri: **; Fert: **; Irri x Fertilizer:N.S.; Year:N.S. Irri: **; Fert: **; Irri x Fertilizer:N.S.; Year:N.S.

Irri: Irrigation level; Fert: Fertilizer doses; *: P $\leq 0.05 ; * *: P \leq 0.01 ;$ NS: non-significant;

I 50: $50 \%$ of depleted water; I 75: 75\% of depleted water; I 100: $100 \%$ of depleted water; N1:100 $\mathrm{kg} \mathrm{ha}^{-1} ; \mathrm{N2:200} \mathrm{kg} \mathrm{ha}^{-1} ; \mathrm{N3:300} \mathrm{kg} \mathrm{ha}^{-1}$

\section{DISCUSSIONS}

Water stress affect metabolic and enzyme activities of plants and this results in changing chemical composition of seed (Carvalho et al., 2004). Moreover, negative effect of water stress on photosynthetic parameters changes chemical composition (Ali et al., 2010). Increase in water stress at this study negatively affected crude oil content so this situation can be explained drought stress, high temperature Triboi and Triboi-Blondel (2002) and variety 
difference Piper and Boote (1999). Ghassemi-Golezani and Lotfi (2013) demonstrated that shot grain filling period under water stress can also explain this phenomenon. Physiologically, stomata of plant are closed under water stress condition, so that reason carbohydrate such as proline and glycine and protein metabolites are accumulated into plant leaves (Pelleschi et al., 1997). These metabolites cannot be transported to grain due to water deficit so protein content in the grain is reduced.

Nitrogen is vital for protein and enzyme synthesis in plants. As all metabolic activities are controlled by enzymes, nitrogen is also included chlorophyll synthesis which absorbs energy for photosynthesis (Islam et al., 2010). Photosynthesis rate is increased in maize crop when nitrogen and water uptake reach to optimum level especially during the grain filling stage (Uribelarrea et al., 2004). Like nitrogen, sugars produced during photosynthesis are also regularly transferred to cobs for grain formation (Swank et al., 1982).

The more carbohydrates in grains mean that the more gas production Blummel and Orskov (1993). Increased irrigation can contribute to more nitrogen in grain due to the fact that vegetative organs can transfer inside nitrogen to grain after flowering stage (Swank et al., 1982). Nitrogen enlarges grain filling period in plants so that reason it can contribute to reuse of nitrogen by plants (Hayati et al., 1995). High amount of nitrogen increases amino acid synthesis, so this results in additional protein accumulation in grains (Patil et al., 1997). In this study, increased nitrogen doses positively affected protein content in the grains. Moreover, combination of irrigation and nitrogen applications contributed to enlarged grain filling stage. As a consequence of this, more plump grains were harvested that consisted of more oil content when compared to shrunken grains under stress conditions Bewley and Black (1994).

Crude ash is vital especially for cell functions in plant and can not be synthesized by animal organism so animal feeds have to be included by crude ash via grains Genctan (1998). In this study, additional irrigation and nitrogen doses increased crude ash content in the grain, in turn, this can ease availability of mineral matters.

Water stress can negatively affect crude fiber in the grain (Ali et al., 2010). This is the clear indicator of ADF and NDF increase in the cell wall but this situation negatively affects crude protein content, gas production, metabolic energy and digestible organic matter (Kaplan et al., 2014). Therefore, increased irrigation and nitrogen doses resulted in lower ADF and NDF ratio while crude protein, gas production and ME and OMD ratios increased in this study. Yang et al. (2004) also indicated that there was a positive correlation between protein and starch contents. The more carbohydrates mean that the more gas emission Blummel and Orskov (1993). This study showed that there was a positive relation between increased protein ratio and gas production. Metabolic energy of maize grain was calculated using the method suggested by Menke and Steingass (1988). This clearly demonstrated that increased crude protein and oil ratios positively affected metabolic energy of maize grain in the study.

Feeds are classified in to three groups based on methane percentage emission which are low (>\%11 and $\leq \% 14)$, medium $(\%>6$ and $<\% 11)$, and high $(>\% 0$ and $<\% 6$ ) anti-methanogenic feeds (Lopez et al., 2010). In this study, anti-methanogenic effects of the maize grain was determined as medium level. Irrigation and nitrogen combination have positively contributed grain composition but these also resulted in higher amount of gas and methane production.

\section{CONCLUSION}

This study clearly showed that increased irrigation and nitrogen applications positively affected crude protein and oil, $\mathrm{ME}$ and OMD and ADF and NDF ratios were decreased which reduce digestibility of maize grain. Moreover, it was observed that energy content and digestible organic matter were also increased due to excessive gas and methane production. Water application close to field capacity and $300 \mathrm{~kg} \mathrm{ha}^{-1}$ nitrogen dose are conveniently suggested to produce high quality maize grain production in the similar ecological conditions and soil traits. Further research on maize grain for animal feeding should be focused in to the total phenolic, antiradical capacity and starch fractions.

\section{ACKNOWLEDGEMENTS}

The authors acknowledge the financial support of the Erciyes University Research Fund (Grand no: FYL-20156131).

\section{LITERATURE CITED}

Ali, Q., M. Ashraf and F. Anwar. 2010. Seed Composition and Seed Oil Antioxidant Activity of Maize Under Water Stress. J Am Oil Chem Soc. 87:1179-1187.

AOAC (Association of Official Analytical Chemists). 1990. Official Methods of Analysis 15. Ed. Arlington, VA, USA: Association of Official Analytical Chemists Inc.

Baenziger, P.S., D.R. Shelton, M.J. Shipman and R.A. Graybosch. 2001. Breeding for end-use quality: reflections on the Nebraska experience. Euphytica. 119:95-100.

Bewley, J.D. and M. Black. 1994. Seeds: Physiology of Development and Germination. New York: Plenum Press.

Blummel, M. and E.R. Orskov 1993. Comparison of in vitro gas production and nylon bag degradability of roughages in predicting of food intake in cattle. Anim. Feed. Sci. Technol. 40:109-119.

Canbolat, O. 2012. Comparison of in vitro Gas Production, Organic Matter Digestibility, Relative Feed Value and Metabolizable Energy Contents of Some Cereal Forages. Journal of the Faculty of Veterinary Medicine, Kafkas University. 18(4):571-577 (in Turkish).

Carvalho, I.S., C.P. Ricardo and M. Chaves. 2004. Quality and distribution of assimilates within the whole plant of lupins (L. albus and L. mutabilis) influenced by water stress. J Agron Crop Sci. 190:205-210.

Ferrer, F., J.M. Villalar, C.O. Stockle, P. Villalar and M. Aran. Impacto del nitrógeno presente en el agua de riego en la zona regable del Canal d'Urgell (Nitrogen impact in irrigation water in the irrigated area of the Urgell's Channel). XV Congreso de Riegos y Drenajes, Lleida, pp. 241-248. 
Genctan, T. 1998. Agricultural Ecology, Trakya University Tekirdağ Agricultural Faculty, Field Crops Departmant, Tekirdağ. p 191 (in Turkish).

Ghassemi-Golezani, K. and R. Lotfi. 2013. Influence of water stress and pod position on oil and protein accumulation in soybean grains. International Journal of Agronomy and Plant Production 4:2341-2345.

Goel, G., H.P.S Makkar and K. Becker. 2008. Effects of Sesbania sesban and Carduus pycnocephalus leaves and Fenugreek (Trigonella foenum-graecum L.) seeds and their extracts on partitioning of nutrients from roughage- and concentrate-based feeds to methane. Animal Feed Science and Technology 147:72-89.

Gul, I., M. Yildirim, C. Akinci, I. Doran, H. Kilic. 2008. Response of Silage Maize (Zea mays L.) to Nitrogen Fertilizer after Different Crops in a Semi Arid Environment. Turk. J. Agric. For. 32: 513-520.

Hayati, R., D.B Egli and S.J. Crafts-Brandner. 1995. Carbon and nitrogen supply during seed filling and leaf senescence in soybean. Crop Sci. 35:1063-1069.

Islam, M.R., S.M.E. Rahman, M.M. Rahman, D.H. Oh and C.S. Ra. 2010. The effects of biogas slurry on the production and quality of maize fodder. Turk J Agric For. 34:91-99.

Kaplan, M., A. Kamalak, A.A. Kasra and I. Guven. 2014. Effect of maturity stages on potential nutritive value, methane production and condensed tannin content of Sanguisorba minor Hay. Journal of the Faculty of Veterinary Medicine, Kafkas University. 20:445-449 (in Turkish).

Khelil, M.N., S.B. Rejeb, B. Henchi and J.P. Destain. 2013. Effects of Irrigation Water Quality and Nitrogen Rate on the Recovery of $15 \mathrm{~N}$ Fertilizer by Sorghum in Field Study. Communications in Soil Science and Plant Analysis 44:2647-2655.

Kim, K., D.E. Clay, C.G. Carlson, S.A. Clay and T. Trooien. 2008. Do synergistic relationships between nitrogen and water influence the ability of corn to use nitrogen derived from fertilizer and soil. Agron. J. 100:551-556.

Kirtok, Y. 1998. The production and use of corn. Istanbul: Kocaoluk Publishing House (in Turkish).

Kusvuran, A., M. Kaplan, R.I. Nazl1, V. Saruhan, Y. Karadag. 2015. Determination of possibilities to grow some corn (Zea mays L.) cultivars for silage production under Middle Kizilirmak Basin ecological conditions. Journal of Agricultural Faculty of Gaziosmanpasa University, 32: 5767.

Lin, B., J.H. Wang, Y. Lu, Q. Liang and J.X. Liu. 2013. In vitro rumen fermentation and methane production are influenced by active components of essential oils combined with fumarate. Anim Physiol Anim Nutr. 97(1):1-9.

Lopez, S., H.P.S. Makkar and C.R. Soliva. 2010. Screening plants and plant products for methane inhibitors. In "In vitro screening of plant resources for extra nutritional attributes in ruminants: Nuclear and related methodologies" ed. Vercoe P.E, H.P.S Makkar, Schlink A, pp: 191-231 New York, USA.
Menke, K.H., L. Raab, A. Salewski, H. Steingass, D. Fritz and W. Schneider. 1979. The estimation of the digestibility and metabolisable energy content of ruminant feedingstuffs from the gas production when they are incubated with rumen liquor in vitro. J Agric Sci Camb. 93 (1):217-222.

Menke, K.H., and H. Steingass. 1988. Estimation of the energetic feed value obtained from chemical analysis and in vitro gas production using rumen fluid. Animal research and development 28:7-55.

Oktem, A. 2008. Effect of water shortage on yield, and protein and mineral compositions of drip-irrigated sweet corn in sustainable agricultural systems. Agricultural Water Management 95:1003-1010.

Patil, D.B., K.T. Naphade, S.G. Wankhade, S.S Wanjari and N.R. Potdukhe. 1997. Effect of nitrogen and phosphate levels on seed protein and carbohydrate content of cotton cultivars. Indian Journal of Agricultural Research 31:133135.

Pelleschi, S., J.P. Rocher and J.L. Prioul. 1997. Effect of water restriction on carbohydrate metabolism and photosynthesis in mature maize leaves. Plant Cell Environ. 20:493-503.

Piper, E.L. and K.J. Boote. 1999. Temperature and cultivar effects on soybean seed oil and protein concentrations. J Am Oil Chem Soc. 76:1233-1242.

Rahman, S.M.E., M.A. Islam., M.M. Rahman and D.H. Oh. 2008. Effect of cattle slurry on growth, biomass yield and chemical composition of maize fodder. Asian-Australasian Journal of Animal Sciences. 21:1592-1598.

SAS. 1999. SAS User's Guide: Statistic. Statistical Analysis Systems Institute Inc. Cary, NC, USA.

Swank, J.C., F.E. Below, R.J. Lamber and R.H. Hageman. 1982. Interaction of carbon and nitrogen metabolism in productivity of maize. Plant Physiol. 70:185-190.

Triboi, E. and A.M. Triboi-Blondel. 2002. Productivity and grain or seed yield: a new approach to an old problem. Invited paper. Eur J Agron. 16:163-186.

Uribelarrea, M., F.E. Below and S.P. Moose. 2004. Grain composition and productivity of maize hybrids derived from the Illinois protein strains in response to variable nitrogen supply. Crop Sci. 44:1593-1600.

Van Soest, P.J. and R.H. Wine. 1967. The use of detergents in the analysis of fibrous feeds. IV. Determination of plant cell wall constituents. Journal of the Association of Official Analytical Chemists 50:50-55.

Van Soest, P.J. 1963. The use of detergents in the analysis of fibre feeds. II. A rapid method for the determination of fibre and lignin. Journal of the Association of Official Analytical Chemists 46:829-835.

Yang, H.M., X.Y. Zhang and G.X. Wang. 2004. Relationships between stomatal character, photosynthetic character and seed chemical composition in grass pea at different water availabilities. J Agric Sci. 142:675-681. 